\title{
Capstone and Cornerstone: Creating a Virtual Research Centre in Honours and Graduate Courses in Renaissance Literature ${ }^{1}$
}

\author{
ELIZABETH POPHAM
}

Trent University

For the past three years, I have experimented with courses for senior undergraduate and first year graduate students that incorporate features of directed reading projects, making use of a Managed Learning System (MLS) site as a "virtual research centre" for collaborative investigation of critical issues in the reading of Elizabethan texts. An honours seminar on "Sex and Politics in Elizabethan England" provided a "capstone" experience for fifteen students conducting independent research projects on a group of core texts. Research logs were posted on "Themes and Issues" pages, and essays were published in a journal on the MLS site. In master's-level classes on "The Life-Cycle of Some Renaissance Texts," a similar system provided a "cornerstone" for graduate studies. Each student adopted a text that presented issues related to publication, authorship, circulation, or historical "afterlife." Work-in-progress was shared in class and on the MLS site, and the group acted as the editorial committee for an online journal.

Durant ces trois dernières années, nous avons exploré des voies pédagogiques sur des cours de troisième et quatrième année, ainsi que des cours de première année du cycle supérieur, qui comportaient des recherches dirigées. Ces tâches de recherche guidée étaient effectuées à l'aide d'une plateforme d'apprentissage informatique (Managed Learning System), fonctionnant comme un centre de recherche virtuel conçu en vue d'une recherche collaborative sur des questions d'interprétation et de critique de textes élisabéthains. Un séminaire de quatrième année (Honours) intitulé "Sex and Politics in Elizabethan England " a donné loccasion à 15 étudiants/es d’acquérir une expérience de recherche indépendante portant sur un ensemble de textes, propre à conclure un diplôme de premier cycle. Les journaux de bord étaient téléversés dans une page dédiée aux "Thèmes et problèmes", tandis que les essais étaient publiés dans une revue hébergée sur la plateforme informatique (MLS). Dans le cours de première année du second cycle intitulé "The Life Cycle of Some Renaissance Texts", une plateforme du même type servait de point de ralliement. Chaque étudiant/e a travaillé sur un texte particulier soulevant des questions relatives à la publication, à la paternité auctoriale, à la circulation, et à sa postérité. Le déroulement de leur travail de recherche était partagé en classe et sur la plateforme informatique, tandis que le même groupe, engagé dans la réalisation d’une revue en ligne, effectuait également les tâches d'un comité éditorial.

1. Versions of this paper were presented at the symposium Electronic Engagement: Enhancing Student Learning through Technology (Trent University, 4 May 2012), and the annual meeting of the Canadian Society for Renaissance Studies (University of Victoria, 1 June 2013). 
$\mathrm{T}$ he academy is currently buzzing with references to "learner-centred environments," "inquiry-based learning," "problem-based learning” (PBL), and "capstone experiences." In the pedagogical literature as well as in vision statements and academic plans penned by university committees, these catchphrases are most often associated with instruction in professional faculties and STEM disciplines (science, technology, engineering, and mathematics) where they are part of a curriculum intended to develop a technologically literate workforce, culminating in internship placements and team projects simulating "real world" situations. ${ }^{2}$ Pressure is being placed on humanities disciplines to provide comparable opportunities for students to participate in "experiential learning." This presents difficulties for departments of English, Cultural Studies, Philosophy, History, and Classics for a number of reasons. Most obviously, there is a less direct connection between humanities disciplines and defined career paths than in professional and technological education. Rather than specific job skills, the focus of a liberal arts degree has always been to produce literate and responsible citizens, and by these criteria our graduates' greatest skills are cultural literacy, moral conscience, the ability to analyze and communicate, and the impetus to make change. To quote the recently published review of the humanities at Harvard University, " $[\mathrm{t}]$ he Arts and Humanities teach us how to describe, evaluate, and change the world": ${ }^{3}$

The terms of art and philosophy are irreplaceable for our articulate description of the world, without which we fall painfully mute. The capacity precisely to describe experience of the world also provokes evaluation

2. Landmark documents in the movement toward experiential and inquiry-based learning are David A. Kolb's Experiential Learning: Experience as the Source of Learning and Development (Englewood Cliffs, NJ: Prentice Hall, 1983), and-in terms of higher education policy-the Boyer Commission on Educating Undergraduates in the Research University: Reinventing Undergraduate Education: A Blueprint for America's Research University (Stony Brook, NY: State University of New York Press, 1998). For a survey and assessment of Kolb's influence, see Michael K. Smith, "David A. Kolb on Experiential Learning," The Encyclopedia of Informal Education (2001; 2010), accessed 26 June 2013, http://infed.org/ mobi/david-a-kolb-on-experiential-learning/. For a survey of arguments in favour of PBL, see Joanna C. Dunlap, "Problem-based Learning and Self-efficiency: How a Capstone Course Prepares Students for a Profession," Educational Technology Research and Development 53 (2005): 65-85.

3. David Armitage et al., "In Brief: The Teaching of the Humanities at Harvard College: Mapping the Future," accessed 14 June 2013, http://artsandhumanities.fas.harvard.edu/files/humanities/files/ final_in_brief_mapping_the_future_may_22_from_mf.pdf, 1 . 
of the world, through the act of deliberative criticism. Our rigorous, receptive responsiveness to art and philosophy provokes an answering responsibility to the world. As we answer, we also seek to harness art's capacity to help us imagine transformation of the world. Every work of art is an act of recreative making. Art thereby models the liberating way in which the world itself might be remade. ${ }^{4}$

To this I would add that one reason to study the literature of the early modern period-and specifically the English literary Renaissance-in the twenty-first century is precisely that it so clearly enunciates the concept that "the highest end of mistress-knowledge, by the Greeks called architectonike [...] stands [...] in the knowledge of a man's self, in the ethic and politic consideration, and with the end of well-doing and not of well-knowing only [...]."5

More practically, at the very time that humanities departments are being asked to think in terms of capstones and PBL, reduced instructional budgets and larger classes at the senior levels, coupled with a shifting of resources to graduate programs (even in "primarily undergraduate" universities), have meant that their ability to offer these in the time-honoured manner-through honours theses and directed reading projects-is seriously threatened. ${ }^{6}$ As a professor of English Literature at Trent University, a primarily undergraduate university that has built its reputation on learner-centred instruction, I have seen my colleagues in the English Department, and the humanities in general, under increasing pressure to take on graduate supervisions and to teach in fields outside their research specializations. Enrolments in the humanities may be shrinking but retiring faculty are not being replaced, and the teaching loads of those who remain are growing. Career evaluation is oriented towards

\section{Armitage, 1.}

5. Sir Philip Sidney, A Defence of Poetry, ed. Jan. A. Van Dorsten (Oxford: Oxford University Press, 1966), 29.

6. An informal survey of chairs of departments of English Literature at forty-one Canadian universities conducted in June 2013 revealed that the thesis option ( 2.0 to 0.5 credits) was available at only eighteen schools. It was required at only six, but was under review or actively discouraged at four. Directed reading projects-independent or in the context of required honours seminars as distinct from thesis projects-were options at nine schools. Practicums or internships were available at six schools (three in the context of Editing, Writing or Education programs), and capstone courses tended to be associated with colloquia. 
production, and the adage "publish or perish" is truer than ever. As academic advisor for the Department of English Literature, I find myself counselling students that the two-credit honours thesis and directed reading course one- or two-semester options may still be on the books, but are seldom available-as faculty with commitments to multiple graduate supervisions are less and less likely to agree to take on overload commitments unless there is a strong connection with their own research.

However, while the independent research project that traditionally served as the capstone of the North American liberal arts degree is under siege, the crisis may afford us a chance to consider whether there might be more effective options. We need to ask ourselves some of the disturbing questions that humanities departments are being bombarded with from outside: What we are trying to teach our students in the course of their studies for the degree? What is the knowledge-base? What is the skills-set? How can we communicate the value of this knowledge and these skills both to employers and to the students themselves? Is the honours thesis the most appropriate conclusion to a degree in the humanities in the second decade of the twenty-first century? Can we retain the best features of the traditional model while introducing a sense of working in a research community? What should a capstone experience in the humanities look like?

\section{The capstone experience}

In architecture, the "capstone" is the final stone placed on a building or other structure-in classical construction, the keystone in an arch. The capstone signifies the completion of construction, but it also serves the very practical purpose of securing the structure. By analogy, a "capstone project" is a large assignment that is meant to be the final piece in the structure of an undergraduate degree, cementing the knowledge and skills acquired over four years of study. Requiring a great deal of research and intellectual engagement, and supervised by a professor or teacher, the traditional capstone project in a liberal arts degree-the honours thesis or directed reading course-is the epitome of learner-centred and project-based instruction. But it is also a solitary enterprise. By contrast, in professional education, the capstone course has generally replaced the individualized project. Calendar descriptions tend to read like this one from Concordia University's School of Engineering and 
Computer Science: "In their final year, students will participate in leadingedge research while doing their Capstone Projects. This project enables students to carry out a team design project from scratch, experience project management, practice their technical writing and presentation skills." In the 2013-14 academic calendar of my own university (Trent) the word "capstone" appears seven times, in association with degree programs in Computer Science and Information Systems, Environmental Science, Business Administration, and Journalism. On the university website, it is used in conjunction with references to "work placements," "co-op placements," "internships," and "apprenticeships." Joanna Dunlap of the School of Education and Human Development at the University of Colorado makes the implied real-world connection explicit when she observes that a "problem-centered learning environment" is integral to capstone projects and courses, in which "the process students follow replicates the commonly used systemic approach to resolving problems or meeting challenges encountered in the workplace and the world at large [...]." In addition to knowledge and skills-including analytical ability, the ability to collaborate, to identify and compensate for weaknesses in the individual and the team-the goal of PBL is the achievement of "selfefficacy": the "level of confidence and self-judgment [...] needed to perform effectively" in the professional context. ${ }^{10}$

These goals will sound familiar to any humanist, with the exception of the emphasis on working as part of a team. The traditional thesis or directed reading course is an individual endeavour, and scholarship in the humanities is popularly associated with images of solitary meditation such as Albrecht Dürer's Melancholy I (although ironically this image predates the schism between the humanities and science, and Lady Melancholy's philosophical deliberations

7. "Capstone Projects," Concordia University: Engineering and Computer Science, accessed 21 June 2013, http://www.encs.concordia.ca/current-students/undergraduate-program-requirements/capstoneprojects/. This page is no longer online; as of 2014, information on capstone projects is found at http:// www.concordia.ca/encs/students/sas/undergrad-program-info/capstone.html.

8. “Trent University Oshawa Hosts Co-op Advantage," Daily News, posted 12 June 2013, http://www. trentu.ca/newsevents/newsDetail.php?newsID=5298.

9. Dunlap, 66.

10. Dale Schunk, "Self-efficacy and Cognitive Skill Learning," in Research on Motivation in Education: Goals and Cognition, ed. C. Ames and R. Ames (San Diego, CA: Academic Press, 1989), 13. 
would be associated today with "pure science"), ${ }^{11}$ or the contemplative life idealized in Milton's "Il Penseroso":

Come pensive nun, devout and pure,

Sober, steadfast, and demure,

All in a robe of darkest grain,

Flowing with majestic train,

And sable stole of cypress lawn,

Over thy decent shoulders drawn.

Come, but keep thy wonted state,

With even step, and musing gait,

And looks commencing with the skies,

Thy rapt soul sitting in thine eyes:

There held in holy passion still,

Forget thyself to marble, till

With a sad leaden downward cast,

Thou fix them on the earth as fast.

And join with thee calm Peace, and Quiet,

Spare Fast, that oft with gods doth diet,

And hears the Muses in a ring,

Ay round about Jove's altar sing [...]

$(\text { lines 31-49) })^{12}$

In these artistic depictions, creative intelligence is associated with isolation, and in our pragmatic age one might well ask-like the cartoonist who placed a graduate's cap on Auguste Rodin's The Thinker- "Now what?” A. D. Nuttall argues in Dead from the Waist Down that the popular image of scholars oscillates between "passionate, devoted heroes of the invisible life" and "dead, sexless,

11. In Dürer's 1514 engraving, the winged figure of Melancholy is surrounded by instruments of scientific measurement: a compass, geometric shapes, an hour-glass, scales and a magic square (consisting of four numbers across and four down, with each line adding up to sixty-four), as well as wood-working tools associated with architecture.

12. The Poems of John Milton, ed. John Carey and Alastair Fowler (London: Longmans, Green and Co., 1968), 141-42. 
tedious." ${ }^{13}$ In the Renaissance, scholars were often depicted as lone figures wielding powerful, even dangerous, magic, but when Francis Bacon "invent[ed] the scientific committee, recommend[ed] the pooling of information," he initiated "the process that will lead in due course to the barren dryness of Mr. Casaubon in Middlemarch." ${ }^{14}$ The assumption is that science is practical and collaborative, and the humanities esoteric and isolating. However, I would counter that the stories of Marlowe's Doctor Faustus and Shakespeare's Prospero are object lessons in the necessity that intellectuals engage with the world. And while Francis Bacon's writing contributed to the subsequent separation of physics from philosophy, and to the assumption that there are abstruse and practical fields of knowledge, he himself did not make the distinction, maintaining that all knowledge that was in accordance with nature had the power to transform human nature and the world. Community is an essential complement to individual study for scholars in the humanities. And, our primary goal for our students-while not as focused as the STEM disciplines on professionalization-is the achievement of "self-efficacy" 15 through engagement and collaboration. In the words of the advertising brochure for the Department of English Literature at Trent University, we expect our students to "engage in lively argument, rise to intellectual challenges, and express [their] best ideas." ${ }^{16}$

But just what is the professional skill-set we are trying to help our students develop? For an answer, let's go to the most mundane of authorities. A handout entitled "What can I do with my studies in English?" on the website for Trent University's Career Counselling Centre offers up a list of "skills developed, sample fields of work, resources, professional associations, alumnistudent mentoring program and more." ${ }^{17}$ The following skills are listed in the section designed to assist English majors in "recognizing valuable assets" they will develop in the course of their studies:

13. A. D. Nuttall, Dead from the Waist Down: Scholars and Scholarship in Literature and the Popular Imagination (New Haven and London: Yale University Press, 2011), ix.

14. Nuttall, 5 .

15. Dunlap, 66.

16. The same brochure goes on to say "When you study English at Trent, you engage with the humanities to make the world around us more critical of power, more generous in spirit, more responsive, and more humane" (http://www.trentu.ca/english/documents/brochure.pdf, accessed 20 June 2013).

17. http://www.trentu.ca/careers/students/documents/English-06.pdf, accessed 20 June 2013, no longer available online. 
- Ability to analyse written material

- Comprehensive command of grammar and vocabulary

- Making oral presentations

- Computer skills - word processing

- Writing creatively and concisely

- Editing skills

- Good listening, clarifying, questioning and responding skills

- Influencing and persuading

- Developing critical evaluations

- Knowledge of the structure and functioning of language

- Shaping/summarizing general ideas into specific points

- Problem solving

- Knowledge of genres, authors, periods, and critical approaches

- Thinking independently

- Understanding the nature of literature and of the various currents in literary criticism

- Ability to be articulate and analytical

- Ability to identify patterns in written material

- Ability to conduct and clearly explain research results

The catalogues of "learning outcomes" mandated by the Ontario government cover much the same territory, and are echoed in significantly more eloquent language in the opening paragraphs of the review of the Arts and Humanities Division at Harvard University published in May 2013:

The Arts and Humanities are the realms in and through which we define values, form relationships, express our thoughts, feel, imagine, process, and create. The study of the Arts and Humanities provides a basic toolkit for personal and professional success: how to communicate what we think; how to interpret what we read, see and hear; how to understand and respond to difference.

Study within humanistic disciplines hones precisely the skills needed to navigate a world marked by rapid change, increasing interdependence, transformative technologies, and multimedia communications. The Arts and Humanities are unique in their potential to help students develop the 
skills and wisdom needed to thrive in the digitized, globalized, discoverydriven economy of the twenty-first century. ${ }^{18}$

Our pedagogy reflects these expectations. Although specific details vary from department to department, and instructor to instructor, we typically combine dissemination of information and the modelling of critical analysis in lectures with opportunities in class discussion for students to work closely with literature under the supervision of the instructor, encouraging analysis of texts, construction and criticism of arguments, and development of oral communication and presentation skills. Students are asked to replicate these processes in their written work, and individual coaching is provided by the instructor in the form of written comments. As students progress into upper year courses, we expect them to work with less direct supervision and to add research skills to their repertoires. Courses become more narrowly focused until, in "advanced studies" seminars at the senior level, students are asked to participate in analysis of texts and issues related to the research interests of the instructor, while graduate seminars provide opportunity for independent research within the disciplinary framework. In recent years, we have extended the classroom electronically, often using Managed Learning System (MLS) sites to post administrative information (syllabuses, grades, etc.) and resource material to supplement in-class instruction, but also to extend discussion and debate outside of class time. And in this digital age, professors and students have access to multiple vehicles for their analyses and are experimenting with blogs, websites, video essays, and multi-platform submissions in place of or to supplement the traditional essay.

Central to both our research and our pedagogy in the humanities is the awareness that scholarship is defined by ongoing discussion and debate over time in multiple forums; that it is not a solitary activity, and that in terms of both academic and professional training, analysis and argumentation are subject to review and assessment-to collaboration before, during, or after the fact. In our teaching, we offer students a version of the process by which our own work is generated, assessed, and published. I would argue that, in designing (and redefining) the capstone experience, we should explicitly draw attention 
to that fact, and invite senior students to participate knowingly in the realworld collaborative process as members of a research community.

\section{Building a research community}

There are many ways in which this sense of participating in a collaborative research community can be accomplished. In an advanced seminar in English literature, students are tracking-consciously or not-to post-degree careers in education, information science, communications, and public relations. A very few will attend graduate school. Capstone experiences should and must give them opportunities not only to conduct independent research but also to present the results of that research in spoken and textual forums where they will be subject to peer review and collaboration. In many undergraduate degree programs, a step in this direction is taken when students in the final year of an honours degree participate in formal colloquia in which they present the results of their work in thesis or directed reading courses. Alternatives to this public display of independent projects might include more inherently collaborative projects-such as editing and annotating a text, ${ }^{19}$ producing a play, or planning a colloquium related to the theme of an existing course or courses. The model I am presenting here evolved from the idea of incorporating features of the traditional directed reading course into a standard honours seminar of fifteen to twenty students. The strategy was to treat the students in the course as a research community. The knowledge-base would be academic, but the skillsset transferrable. Each student would have his or her own independent research project associated with a communal exploration of the course topic. Although I had mapped out a tentative schedule of readings in the syllabus, this would be subject to minor changes depending on the areas of investigation chosen by the students.

19. For an example of project-based pedagogy, see Joel E. Salt, Allison Muri, and Ronald Wayne Cooley, "Electronic Scholarly Editing in the University Classroom: an Approach to Project-based Learning," Digital Studies/Le champ numérique 3.1 (2012), http://www.digitalstudies.org/ojs/index.php/digital_studies/article/view/212/267. Students in an honours seminar at the University of Saskatchewan engaged with editing theory and practice in the process of preparing and publishing electronic documentary editions of two seventeenth-century books: the anonymous Eighth Liberal Science: or a New-found Art and Order of Drinking (1650), and Edward Whitaker's Directions for Brewing Malt Liquors (1700). 
The course was ENGL 4153H (Advanced Studies in Renaissance Literature), and the topic was "Sex and Politics in Elizabethan England." Here is the description of the material and the issues that was distributed to the fifteen students before our first meeting:

From 1558 to 1603, Elizabethan England found itself in the paradoxical position of being ruled by a female prince. As a result, while there are few women writers in the period (and even fewer of note), Elizabethan literature demonstrates an unusual preoccupation with gender and relationships between the sexes, and simultaneously with emotional and political power. Literary kinds which conventionally reflect the maledominated sphere of "ethic and politic consideration" (as Sir Philip Sidney calls it in his Defence of Poesy) expanded to incorporate lyric and pastoral, genres focussed on private and emotional concerns. As writers searched for alternatives to the martial metaphors traditionally associated with kingship, it became increasingly difficult to draw a distinct line between the languages of romantic and political courtship.

We will focus our exploration of the phenomenon of Elizabethan "court[ier]ship" on Sidney's Old Arcadia; Books 3 and 5 of Edmund Spenser's The Faerie Queene; and selected poems and plays of William Shakespeare (including Venus and Adonis, Henry V, and Antony and Cleopatra). Examples of "courtesy" literature, contemporary political and poetic theory, prose romance, and political pageantry will provide a context for our examination of these central texts.

As a first step in building a scholarly community, this description defined three broad areas of investigation: (1) Elizabethan literature; (2) its social, political, and religious context; and (3) the cultural impact of humanist educational reforms. It also established a set of shared questions, the most central being how a self-consciously progressive but patriarchal culture copes with the paradox of female power, and how those coping mechanisms are reflected in its literature.

At our first meeting, students were asked to choose a topic of investigation on which they would become the "class experts." Some of these were grounded in formal qualities of the literature: rhetoric and style, genre (e.g., sonnet/lyric, pastoral, history, epic, tragedy, courtesy books, etc.), classical mythology, emblems and iconography, and Renaissance critical theory. Topics like chivalry, 
courtly love, Neoplatonism, and humanism were intended to encourage students to explore the history of ideas, and specifically the transition from medieval to Renaissance culture. Other topics directed them towards consideration of how literature functioned in the social context: court and civic pageantry, Elizabethan politics and political writing, the Reformation in England, and material culture (e.g., clothing, landscape, or architecture). Some allowed them to explore the roots of contemporary concerns and issues such as gender and sexuality, power relations, or cultural capital, either through Renaissance writing on the subjects, or through the filter of modern critical or cultural theory.

Our initial survey of the list of "expert fields" provided an opportunity to introduce students to themes and issues that we might explore in the course, and to emphasize that the findings of the research community we were forming would depend on the areas of investigation they chose. Each of us would view the primary material from a different perspective, and therefore would be conscious of different aspects of the texts and the social and cultural milieu in which they were produced. By comparing notes, we would have the opportunity to see much more detail than any individual research project would bring to light. Although I had pre-determined the "core" texts we would address, additional readings might be added to permit individuals to explore areas of special interest. If a member of the class chose to focus on "pastoral," we would add pastoral lyrics to the reading list. If someone chose to focus on "pageantry," we might read The Quenes maiesties passage through the citie of London to westminster the daye before her coronacion (1558), and/or one or more records of great house entertainments. If particular critical approaches to literature (e.g., New Historicism or eco-criticism) were chosen as a research field, we would add samples of critical writing to the course readings. I also emphasized that the list of possible expert fields I had offered was not exhaustive and that each would open up an expansive territory that would have to be narrowed significantly as class members moved forward with their explorations. Finally, although the goal was to assist members of the class in producing well-researched, well-reasoned research papers, I left the door open for alternative assignments appropriate to their field of investigation: for example, notes towards the staging of a play, editing and/or detailed annotation of a text, adaptation of a non-dramatic text (such as a sonnet sequence or narrative poem) for performance, or digital or video "essays." 
Whatever topic was chosen, each student would keep a research log containing an informal record of his or her discoveries. Each would deliver two research updates during the term, consisting of an annotated bibliography and a brief note on preliminary plans for the research project, as well as a brief (five to ten minute) oral presentation in class. Each would also deliver one seminar report (fifteen minutes, with an additional fifteen minutes for discussion and feedback) on the connections between the "expert field" and a "core" text (or a suitable demonstration text). The following week, notes and a reflective assessment of the presentation and discussion, and a plan for improving it, would be submitted. These three assignments-the two research updates and presentation-were scheduled at regular intervals during term, and so, starting in Week 4 , there would be multiple presentations of one sort or another in each seminar.

In keeping with the aim of providing students with research skills and the experience of participating in a research community, assignments in the course were conceived of as both developmental and incremental. They were "developmental" in the sense that each task would provide opportunities to acquire competencies in research and academic writing and to process feedback from fellow students and the instructor before moving on. They were "incremental" in that each step would lay a foundation for the next, contributing to the exploration of the expert field and having the potential to be integrated into the scholarly article they were writing. Predictably, strong students excelled, while weaker students had opportunities for consultation and improvement.

In the first offering of the course, the class bonded to an extraordinary degree, taking their responsibilities as a "research community" very seriously. As the weeks proceeded, students not only exhibited increasing confidence in their knowledge of their own research fields but-where fields inevitably overlapped-they also made recommendations to other students for further reading, contributed with great enthusiasm to the discussions following "applications" of research to texts, and instituted an informal system of peer review. By Week 8 , they were sufficiently engaged in the outcome of each other's research that they suggested that the final papers be published so that they all could read them. This resulted in the creation of the course journal that we eventually called English Renaissance Literature@Trent (ERL@T).20 


\section{The virtual research centre}

One reason for the extraordinary engagement of this first class was that publication was built into the system from the start through the medium of an MLS site. (In the first offering of the course, the site was on WebCT, after which Trent University switched to Blackboard 9.) In conceiving of ENGL-4153H as a research community, I was aware that students who were relatively inexperienced with using secondary sources would need support. While the website for the Trent University Library does a good job of making the library catalogue, research bibliographies, full-text databases, and other resource materials available to students, the effect on the uninitiated can be disorienting. However, within the context of a single course on Renaissance literature with a distinct thematic focus, I would have the opportunity of introducing senior undergraduate students to the wealth of resources available to them as researchers in a controlled environment in which their utility would become obvious.

I decided to set up a "virtual research centre" that would be developed over the course of the term. The MLS site for ENGL-4153H presented to the students on the first day of class contained several folders: (1) "Syllabus and General Information" (containing administrative information and technical resources such as advice on creating annotated bibliographies, and links to "professional" examples such as The Spenser and Sidney World Bibliographies); (2) "Online Coursepack" (for additional readings); (3) "Renaissance Backgrounds" (with links to sites such as Luminarium, Renascence Editions, The English Renaissance in Context [The Schoenberg Center for Electronic Text and Image], ITER: Gateway to the Middle Ages and Renaissance, etc.); and (4) "Themes and Issues." Under “Themes and Issues," separate folders were set up for each of the expert fields, containing a preliminary bibliography to launch the student who chose that topic on his or her way. Here are some samples:

\section{Chivalry}

A medieval concept adhered to and revised in the Renaissance. Starting points for investigation include Maurice Kean, Chivalry (1982) and Alan Young, Tudor and Jacobean Tournaments (1987), as well as articles on "chivalry," "pageants" and "tournaments" in The Spenser Encyclopedia (2000). For background, you might also look into Lawrence Stone's The Crisis of the Aristocracy, 1558-1641 (1967). 


\section{Pageantry}

This topic overlaps with "chivalry." Good starting places for a study of Elizabethan pageantry include acquainting yourself with actual pageants such as Elizabeth's Coronation Entry into London (1558) and a selection of entertainments offered up to her by aristocrats and cities during her summer progresses in collections such as Jean Wilson's Entertainments for Elizabeth I (1984). Roy Strong's The Cult of Elizabeth (1977) offers a survey of the iconography of Elizabethan pageantry. David Bergeron's English Civic Pageantry, 1558-1642 (1970) and The Progresses, Pageants, \& Entertainments of Queen Elizabeth I, edited by Jane Archer, et al (2007) are also recommended.

\section{Theatre and staging}

You will want to investigate the Elizabethan theatre as well as modern productions of the plays in the course as the original theatrical context will have had a profound effect on their composition. In addition to the chapters on players and playhouses in collections such as The Bedford Companion to Shakespeare (1996) and The Cambridge Companion to Shakespeare Studies, edited by Stanley Wells (1986), I suggest that you start with Andrew Gurr's The Shakespearean Stage 1574-1642 (1970). With the modern reconstruction of the Globe Theatre, there has also been a lot of research into Elizabethan theatre design. For a starting point, see John Orrell's The Human Stage: English Theatre Design, 1567-1640 (1988), and Orrell and Gurr's Rebuilding Shakespeare's Globe (1989).

\section{Material culture (clothing)}

Clothing had a significance derived from the "allegorical frame of mind" of Elizabethan culture. Costuming was a major device for establishing setting and characterization in Renaissance theatre as well as in other genres of literature. To begin to gauge its meaning, you will first need to know about the "sumptuary laws" governing what people of different classes were permitted to wear: see Maggie Secara, Elizabethan Sumptuary Statutes: Controlling the Uncontrollable (online 2001). For more information, see Alan Hunt's Governance of Consuming Passions: A History of Sumptuary Laws (1966). Some basics of Renaissance fashion are surveyed by Dolores Monet in "Renaissance Fashion: Elizabethan Women's Clothing" and 
Renaissance portraits provide details of aristocratic costuming. See also Renaissance Clothing and the Materials of Memory (2001) by Ann Rosalind Jones and Peter Stallybrass.

Once students committed to their research fields, their names were attached to the folders, with notations of the dates on which they would be presenting their research updates and seminar reports. Students were responsible for maintaining their folders over the course of the semester. ${ }^{21}$ Some of the items they were expected to post were their annotated bibliographies, the handouts or PowerPoint slides used in their formal seminar reports, and any links or additional material related to their topics that they decided to share with their colleagues. The additional material they posted of their own accord ranged from definitions of key terms for their studies to images from Renaissance art, PDFs of primary texts from Early English Books Online, reviews of books and performances, and links to useful webpages. These digital portfolios were open to all members of the "community," and students referred each other to the resources they had identified.

Although publication in the class journal was optional, all fifteen students elected to participate. Here are some of the projects that came out of this undergraduate research group:

Expert field - Rhetoric and Style

Seminar application - Rhetorical Strategies in Sir Philip Sidney's Defense of Poesie Research paper - The Romance of Rhetoric in Shakespeare's Henry V and Antony and Cleopatra

Expert field - Iconography

Seminar application - The Iconography of the Woman Warrior in Book V of The Faerie Queene

Research paper - Constructing an Image of Queen Elizabeth: The Iconography of Power

Expert field - Material Culture (Clothing)

Seminar application - Clothing and Characterization in Sidney's Old Arcadia

21. In this initial offering, students submitted material to me for posting. Formal assignments-such as the annotated bibliographies-were returned with comments and copy-edited by the students before posting. 
Research paper - Cross-dressing in Edmund Spenser's The Faerie Queene, Book 5 and Sir Philip Sidney's Old Arcadia

Expert field - Theatre and Staging

Seminar application - Elizabethan and Modern Cinemagraphic Staging of Shakespeare's Henry $V$

Creative project - Natural Selection (a play exploring the evolution of Shakespearean staging)

\section{Capstone and cornerstone}

The next year, I continued to explore the research community concept with a mixed group of graduate and undergraduate students in a combined offering of ENGL-4153H (Advanced Studies in Renaissance Literature) and ENGL$5201 \mathrm{H}$ (Topics in the Circulation of Texts) focused on "The Life-cycle of Some Renaissance Texts." With two populations of students, I found myself trying to provide both a capstone for several senior undergraduate students tracking to graduate school, and a cornerstone for graduate students in the first year of Trent's master's program in English Literature, with its distinctive focus on "public texts." The Public Texts program focuses on the material production and circulation of texts, as well as the relationship between texts and their publics. Students can elect to write a traditional thesis, or can take additional courses and either write a major research paper (fifty to sixty pages) or complete an internship with an associated research project (thirty to forty pages). While the program prepares graduates for further study in a range of doctoral programs directly and indirectly related to the field of public texts such as English Literature, Print Culture or The History of the Book, the intention is that all students have opportunities to develop professional skills applicable to fields such as publishing, editing, communications, journalism, information science and archival work. Not surprisingly, the quasi-professional focus of the program contributed to a somewhat different approach to the texts than in a conventional English Literature degree program. Both the undergraduate and graduate students in the class had chosen to take my course to learn more about Renaissance literature, but also to explore the social and cultural implications of the new technologies of print and the theatre. Some of the graduate students would be going on to combine their studies at Trent with the Humber College 
Creative Book Publishing Program, ${ }^{22}$ after which they would find internship placements in publishing houses.

While the capstone completes and secures a structure, a cornerstone is the first stone set in the construction of a building's foundation. All other stones will be set in reference to this stone, determining the position of the entire structure. As my own graduate courses focus on early literature, they are always offered in the Fall term, in which the foundations of graduate level research are being laid. With this in mind, I decided to take the concept of the research community one step further by giving students unprecedented control over the content of the course. Here is the description of our collaborative project that I presented to students prior to our first meeting:

In the final decades of the sixteenth century, the educational reforms of humanism and the emphasis on personal interpretation of scripture that culminated in the Reformation encouraged a new sense of individualism. In the political sphere, the result was a challenge to the traditional separation of authority and "the people." In the print trade, authors began to demand input into the production of texts and publishers began to cater to popular tastes, producing an unprecedented range of texts for different audiences. The burgeoning print trade, the proliferation of literacy and the establishment of the first permanent theatres fostered the beginnings of a modern reading and viewing "public." And yet-especially compared to the late seventeenth and eighteenth centuries-we know very little about the production and circulation of later sixteenth and early seventeenth-century texts in England. The Stationers Register recorded official permissions to print; and Pollard and Redgrave's Short-title catalogue of books printed in England, Scotland and Ireland, and of English books printed abroad 1475-1640 provides a list of printed texts that have survived to be catalogued. Between these two there is a significant gap. Many Elizabethan and Stuart writers "published" to manuscript rather

22. The Creative Book Publishing Program at Humber College's School of Creative and Performing Arts is described on its website as "combin[ing] creativity and entrepreneurship with the only opportunity in Canada to specialize in literary agenting/rights management and publishing technology. Taught by working professionals, and visited by industry gurus and established writers, students of this program regularly make valuable contacts" (http://www.humber.ca/program/creative-book-publishing). 
than print, and truly "popular" books—-printed on poor quality paperwere literally read to bits.

In this course, we will examine the life-cycle of a number of representative texts from the period, from their origins in manuscript or print to the new forms in which they are preserved in the twenty-first century, and their fortunes in the intervening centuries as "canonical" or "non-canonical" texts. These works will span a range of genres, target audiences, modes of publication, authorial influence over publication and circulation in the period, contemporary reputation, and historical "afterlives."

The list of core texts - the ones with which we would begin our investigations-was brief, consisting of the poems of Wyatt and Surrey (first circulated in coterie manuscripts in the 1520s and 30s before being published in Richard Tottel's Miscellany in 1557) and Spenser's The Shepheardes Calendar (a carefully designed presentation of text and author as "laureate" in 1579). The rest would be chosen by the students themselves from a list of texts that would provide interesting fodder for "life-cycle" studies. For example, George Gascoigne's The Adventures of Master F.J. is a prose romance presented as a pirated "coterie" manuscript with commentary that features a fascinating interplay of actual and fictional paratext. Angel Day's Daphnis and Chloe illustrates the Elizabethans' fascination with pastoral, and particularly the Greek romance, but also their very different concept of "translation." Raphael Holinshed's The Chronicles of England, Scotland, and Ireland demonstrates England's imaginative reconception of itself as a nation state, and Shakespeare's history plays witness the remediation of that narrative for the popular theatre. The religious allegory of book 1 of Spenser's Faerie Queene morphs in books 3 and 5 into a complex examination of gender and politics in Elizabethan England, and the paratextual apparatus of the published text positions it for canonical status. Ben Jonson's The Masque of Queens is a rare English example of the festival book genre, and raises issues of the interplay between performed and published texts. And finally, Aemilia Lanyer's Salve Rex Judaeorum is an early example of women's writing and female patronage. However, in a moment of inspiration (or weakness), I added that I would be open to other suggestions if they met the course criteria. This is why the final list of texts included-in addition to Gascoigne's 
Master F.J., Shakespeare's Richard II, and Lanyer's Salve Deus Rex JudaeorumAntony and Cleopatra, The Tempest, and The Book of Common Prayer!

As in the previous course, the students' projects would culminate either in a scholarly article - this time on some aspect of the publication or circulation history of the texts they had chosen-or in the introduction to an edition of a Renaissance text for a twenty-first-century audience. However, the research portfolio was more focused. Essentially, students would collect the sort of information that would be gathered by an editor of a Renaissance text, compiling a publishing history of the primary text; information about sources and/or generic influences; details of the text's reproduction and circulation (including performance in the case of theatrical works); evidence of reception, both in the Renaissance and later periods; an annotated bibliography of primary and critical reading; and an informal record of discoveries and the evolution of the research project. In addition to brief progress reports at regular intervals during the term, students would make two class presentations: an analysis of the "paratext"23 - the apparatus and physical presentation-of the first printed edition of their text (with graduate students adding an analysis of an "interesting" later edition); and a "conference paper" on a topic related to their text.

The chosen texts were required reading for the rest of the class, and each student was invited to assign other primary and/or secondary readings related to his or her text-within reason and in consultation with the instructor. As in the previous year, the MLS site provided a hub for the research community, with each student maintaining a folder devoted to his or her text on which he or she posted information for the class, including-in addition to the annotated bibliography that was the core of his/her research log-definitions, digital images of the first print edition of the text (downloaded from Early English Books Online), information about printers and publishers, links to source material, critical articles, etc.

As the class journal was now part of the plan rather than a late addition, the previous issue was posted, along with copies of the submission guidelines for a number of journals devoted to Renaissance literature and history (including Renaissance and Reformation/Renaissance et Réforme, English Literary

23. In Paratexts: Thresholds of Interpretation (New York: Cambridge University Press, 1997), Gerard Genette uses the term to describe the various conventions that mediate between the text and its audience, including (among others) the author's name, titles, publisher's marks, dedications and inscriptions, prefaces, and notes. 
Renaissance, and Renaissance Quarterly). The graduate students served as the editorial committee, making decisions about our journal's style and design, and determining what issues should be addressed in the preface that they insisted I should write. Unfortunately, time did not allow for formal peer-review of the papers, but they were submitted earlier than in most senior and graduate classes, and returned with the instructor's comments for copy-editing. The journal was published before the end of the examination schedule.

The articles produced in this first iteration of the life-cycle research project included a theopolitical analysis of the English prayer-book tradition, a study of the Hollow Crown production of Richard II, a comparison of the propaganda surrounding the historical Cleopatra and Shakespeare's fictional portrait in the years following the death of Elizabeth I, an analysis of Peter Greenaway and Neil Gaiman's remediations of The Tempest in film and the graphic novel (respectively), and a prospectus for an e-book edition of Aemilia Lanyer's Salve Deus Rex Judaeorum. This year, with a class exclusively consisting of graduate students, projects included a study of the impact of the 1908 discovery of the manuscript of Sidney's Old Arcadia, analyses of children's versions of book 1 of Spenser's Faerie Queene and of a work of young adult fiction based on Holinshed's and Shakespeare's portraits of Macbeth, a history of the figure of Cressida, and an examination of the place of Ben Jonson's Masque of Blackness and Masque of Beauty in the European festival book tradition.

\section{Conclusions}

I began this essay by describing the recent vogue in pedagogical literature for phrases like "learner-centred environments," "inquiry-based" and "problembased" learning, and "capstone experiences." And I asked what a capstone experience in the humanities-and more specifically, in a degree in English literature-might look like. Historically, our capstone project would have been a directed reading course or thesis project. However, not only are these less and less frequently available to students, but they omit by their very nature collaboration and peer review - two essential elements of the experience of any professional writer or researcher. By structuring honours seminar courses as research communities, in which each student undertakes an individual project that illuminates one perspective on a shared set of issues, we can have the best of both worlds, and can offer our students the sort of experiential and 
problem-based learning that will contribute to their sense of themselves as scholars and researchers-in-training. Whatever professional path they take in the future, this self-efficacy and professionalism will stand them in good stead.

I find myself speaking here in generalities, but in a final note, I want to speak as a life-long student and long-time teacher of Renaissance literature. For me, the most exciting part of the experiments I have described in this paper has been the collaborative exploration of a historical period and culture that I love with groups of senior undergraduate and graduate students energized and empowered by taking ownership of the learning process. I have set up the basic architecture of the courses, but they have been busy designing and redesigning the rooms, and doing it very well. 